\title{
C-myc oncogene expression in anal squamous neoplasia
}

\author{
O A Ogunbiyi, J H Scholefield, K Rogers, F Sharp, J H F Smith, S V Polacarz
}

\begin{abstract}
Aims: To determine the pattern of c-myc oncogene expression in anal squamous neoplasia and to determine if this could be used as a marker of disease progression. Methods: The presence and localisation of the c-myc gene product p62 in archival specimens of anal squamous epithelium, normal and neoplastic, was examined using immunohistochemical staining with the monoclonal antibody Myc1-6E10. Ten normal anal epithelia, 10 anal intraepithelial neoplasia (AIN) III, and 31 anal squamous cancers were examined.

Results: There was a noticeable difference between the staining characteristics of invasive tumours, normal anal epithelium, and AIN III. Intense, diffuse, mixed nuclear and cytoplasmic $(n=14)$ and exclusively nuclear $(n=8)$ staining in 22 of 31 (71\%) of invasive anal tumours was observed. All positively staining tumours were well differentiated histologically, while the negatively staining nine of $31(29 \%)$ were poorly differentiated $(n=7)$ and moderately well differentiated $(n=2)$. In six positively staining tumour sections adjacent areas of AIN III and non-dysplastic anal epithelium had staining characteristics similar to those of the invasive component. Staining in both normal anal epithelium (4/10) and AIN III specimens obtained from patients without a history of invasive disease (8/10) was less intense, focal in distribution, and exclusively nuclear. No difference in staining characteristics could be detected in these two groups.

Conclusions: The results of this study suggest that c-myc oncogene expression is implicated in the pathogenesis of anal squamous neoplasia, and that immunohistochemical staining for c-myc protein may be helpful in identifying those AIN III lesions most likely to progress to invasive tumours.
\end{abstract}

(f Clin Pathol 1993;46:23-27)

Cellular oncogenes or proto-oncogenes are a group of regions that have been conserved on the normal genome and which are the cellular homologues of retroviral genes with transforming ability. ${ }^{12}$ These genes and their protein products are thought to have an important role in early development. ${ }^{3}$ They may also be involved in the control of cellular growth, ${ }^{4}$ differentiation, ${ }^{5}$ and tissue repair processes. ${ }^{6} \mathrm{~A}$ change in the coding or controlling regions of these genes by a variety of mechanisms, such as gene amplification, translocation, and mutation have been implicated in the pathogenesis of malignant transformation in several different human tumours. ${ }^{17-10}$

Cellular $m y c$ (c-myc) oncogene was first identified as a homologue of the transforming sequence of MC29, the avian myelocytomatosis virus, ${ }^{11}$ and has been found to be amplified in a wide variety of human cancer lines including small cell lung carcinoma, ${ }^{72}$ breast cancers, ${ }^{13}$ and COLO 320 carcinoma ${ }^{14}$ as well as in fresh human tumours. ${ }^{15} 16$ In addition, a significant number of colon carcinomas have also been shown to overexpress the c-myc gene in the absence of gross genetic changes at the locus, suggesting that deregulation of the c-myc gene may occur by mechanisms other than gene alteration. ${ }^{17}$

Several studies have shown that c-myc is overexpressed due to amplification or rearrangement of the gene and increased messenger RNA and protein product stability in different grades of cervical intraepithelial (CIN) and cervical squamous cell carcinomas. ${ }^{91819}$ Overexpression has been shown to have prognostic importance. ${ }^{20}$ The present study addresses the presence and localisation of the c-myc protein in normal anal epithelium, high grade anal intraepithelial neoplasia (AIN), and anal squamous cancer, using a monoclonal antibody directed against the c-myc protein-p62. Monoclonal antibodies directed against this epitope have already been used successfully in immunohistochemical evaluation of cervical, ${ }^{1821}$ colonic, $^{2223}$ and testicular neoplasia. ${ }^{24}$

\section{Methods}

Fifty one specimens were studied. These comprised 10 normal anal epithelia, 10 AIN III (taken from patients without histories of invasive disease), and 31 squamous cancers. Six of the squamous cancer specimens contained adjacent areas of AIN III and non-dysplastic anal epithelium. These were taken from archival files of the histopathology departments at the Northern General Hospital, Sheffield, and St Mark's Hospital, London. Histology on all specimens was reviewed. The specimens had been previously fixed in $10 \%$ buffered formalin phosphate and paraffin wax embedded. Sections ( $5 \mu \mathrm{m}$ thick) were cut and placed on poly-L-lysine coated glass microscope slides and oven dried at $37^{\circ} \mathrm{C}$ overnight.

STAINING TECHNIQUE

Sections were dewaxed in xylene and hydrated through graded alcohols to deionised water. 
The staining technique used is a modification of the labelled avidin-biotin horseradish peroxidase technique ${ }^{25}$ using the Dako quick staining labelled streptavidin-biotin-avidin kit (Dako LSAB; Dako Ltd, Buckinghamshire, England). Endogenous peroxidase was blocked by a five minute incubation in 3\% hydrogen peroxide. The sections were washed briefly with distilled water and sequentially incubated for 30 minutes each in prediluted non-immune goat serum (Dako LSAB kit) as a blocking agent to minimise non-specific binding, mouse monoclonal antibody Mycl-6E10 (Cambridge Research Biochemical, Cheshire, England) used in a 1 in 300 dilution $(6 \mathrm{ng} / \mathrm{ml})$ in phosphate buffered saline with $0.1 \%$ sodium azide and $0 \cdot 1 \%$ triton $\mathrm{X}-100(\mathrm{pH} 7 \cdot 2)$, prediluted biotinylated anti-mouse secondary antibody (Dako kit), and peroxidase conjugated streptavidin (Dako LSAB) which was diluted with $0.05 \mathrm{M}$ TRIS/ $\mathrm{HCl}$ buffer $(\mathrm{pH} \mathrm{7.6)}$ and freshly prepared according to the manufacturer's instructions.

Washing in TRIS-buffered saline ( $\mathrm{pH} \mathrm{7 \cdot 6)}$ was carried out after each incubation, and following the final washing in TRIS-buffered saline, the peroxidase reaction was developed by application of $\mathrm{DAB}$ solution $(1 \mathrm{mg} / \mathrm{ml}$ diaminobenzidine in $0.05 \mathrm{M}$ TRIS/ $\mathrm{HCl}$ buffer activated with $7.5 \mathrm{ml} 10$ vol $\mathrm{H}_{2} \mathrm{O}_{2}$ immediately before use). The reaction was allowed to develop for 20 minutes, after which it was stopped by washing in distilled water. The sections were then lightly counterstained with Mayer's haematoxylin, dehydrated in ascending grades of alcohol, fixed in xylene and then mounted. A positive result is indicated by brown staining of the nucleus or cytoplasm, or a combination of both.

SPECIFICITY OF ANTIBODY AND CONTROLS Specificity of the Mycl-6E10 antibody has been investigated before and its immunoreactivity found to be annulled by addition of the peptide as immunogen in the production of the antibody. ${ }^{26}$ COLO 320 HSR p62 $2^{\text {c-myc }}$ expressing cells (Public Health Laboratories, Porton down, Salisbury) which were fixed on glass microscope slides using $10 \%$ buffered formol-saline and sections of colon adenocarcinoma, known to express p62 c-myc, were used as known positive controls; non-immune mouse serum was used in place of the primary antibody in sections of anal tissue (normal, AIN III and invasive carcinoma) and used as negative controls. The primary antibody was titrated to the lowest dilution with acceptable background (non-specific) staining.

\section{Results}

The distribution and intensity of p62 ${ }^{\mathrm{c}-m y c}$ with Mycl-6E10 within cells was graded according to whether the pattern of staining was nuclear, cytoplasmic, or mixed. The pattern of immunostaining of the sections in terms of the percentage of positively staining cells was also assessed. Sections with more than $50 \%$ positively staining epithelial cells were classed as having a diffuse staining pattern. Those specimens with less than $50 \%$ positively staining epithelial cells (in groups of cells or isolated scattered cells) were classed as having a focal pattern. The intensity of staining was graded as 0 no staining; + minimal staining; ++ moderate staining; +++ heavy staining. Assessment of the staining patterns was made by two independent observers. A summary of the staining patterns observed is shown in table 1 .

There was a noticeable difference in the distribution and intensity of staining between invasive tumours and normal anal epithelium and AIN III. Twenty two (71\%) of the invasive anal squamous cancers stained positively for p62 c-myc protein. These were all well differentiated tumours, the negatively staining tumours consisting of seven poorly differentiated and two moderately well differentiated tumours. The tumours stained strongly, with over $50 \%$ of the tumour cells staining positively. The intracellular distribution of the stain was mainly mixed cytoplasmic and nuclear $(n=14)$, although in eight of the tumours the staining was exclusively nuclear. In six of the positively staining tumours,

Table 1 Immunohistochemical staining characteristics of anal epithelial tissue for p62

\begin{tabular}{|c|c|c|c|c|c|c|c|}
\hline \multirow[b]{2}{*}{ Specimen } & \multirow[b]{2}{*}{$\begin{array}{l}\text { Total } \\
\text { number }\end{array}$} & \multirow{2}{*}{$\begin{array}{l}\text { No of } \\
\text { positives } \\
(\%)\end{array}$} & \multicolumn{3}{|c|}{ Intracellular staining } & \multirow[b]{2}{*}{ Intensity } & \multirow{2}{*}{$\begin{array}{l}\text { Distribution } \\
\text { Focal }(F) / \\
\text { Diffuse (D) }\end{array}$} \\
\hline & & & Cytoplasmic & Nuclear & Mixed & & \\
\hline $\begin{array}{r}\text { Normal anal } \\
\text { epithelium }\end{array}$ & 10 & $4 \quad(40)$ & - & 4 & - & $+1++$ & $\mathrm{F}$ \\
\hline $\begin{array}{l}\text { AIN III } \\
\text { No evidence of invasion }\end{array}$ & 10 & $8 \quad(80)$ & - & 8 & - & $\left(^{\star}\right)+1++$ & $\mathrm{F}$ \\
\hline $\begin{array}{l}\text { AIN III } \\
\text { Adjacent to invasive tumour }\end{array}$ & 6 & 6 & - & 6 & - & ++ & $\mathrm{D}$ \\
\hline $\begin{array}{l}\text { Ca } \\
\text { Well and moderately } \\
\text { differentiated }\end{array}$ & $24 \dagger$ & $22 \quad(71)$ & - & 8 & 14 & +++ & $\mathrm{D}$ \\
\hline $\begin{array}{l}\mathrm{Ca} \\
\quad \text { Poorly differentiated }\end{array}$ & 7 & 0 & - & - & - & 0 & - \\
\hline
\end{tabular}

* 1 tumour stained intensely $(+++)$ and the distribution was diffuse.

Includes tumours with adjacent areas of AIN III and non-dysplastic epithelium. 


Immunohistochemical
staining of p62 c-myc with
Myc I-6E10 in anal
neoplasia. (A) Invasive
anal tumour showing
mixed cytoplasmic and
nuclear staining;
(B) another tumour
showing exclusively nuclear
staining; (C) same tumour
as in (B) without primary
antibody; (D) intense,
diffuse staining of AIN III
with focus of early invasive
tumour (arrow); (E) and
(F) normal anal
epithelium and AIN III
(from patient without
evidence of invasive
disease), respectively, in
which the distribution of
staining is focal, occurring
mainly in the basal
epithelial layers, with
occasional staining of
mature cells nearer the
epithelial surface. The
staining was less intense
than in invasive tumours.

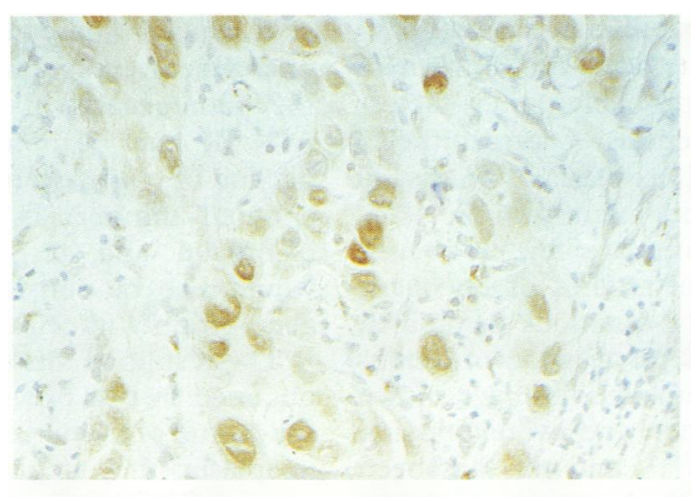

(A)

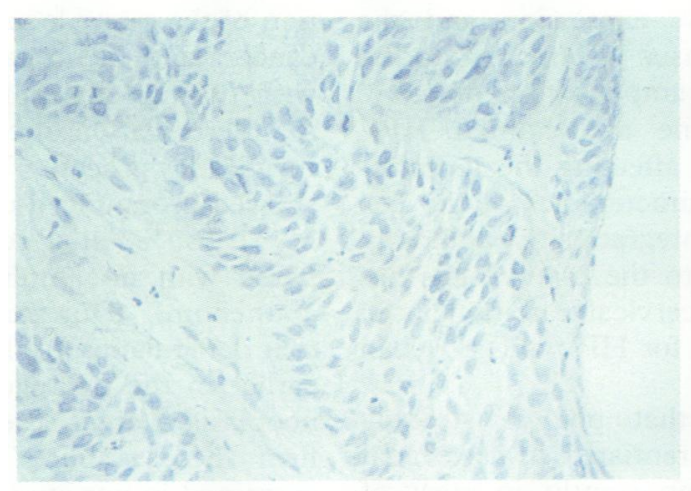

(C)

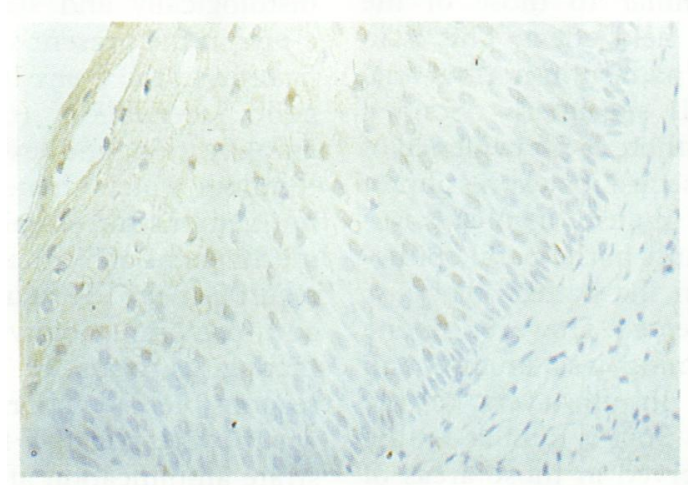

(E)

adjacent areas of AIN III and non-dysplastic epithelium were present. The staining characteristics of these areas were similar to those of the invasive components (figs $1 \mathrm{~A}-\mathrm{D}$ ).

Forty per cent $(4 / 10)$ of normal anal epithelium and $80 \%(8 / 10)$ of AIN III (obtained from patients without evidence of invasive disease) stained positively for p62 c-myc protein. We could not detect any difference in the pattern of expression of the c-myc protein in these two groups. Staining was of mild to moderate intensity and the distribution was focal, mainly occurring in the basal epithelial cells, with occasional mature squamous cells staining positively near the epithelial surface (figs $1 \mathrm{E}$ and $\mathrm{F}$ ). The intracellular distribution of the stain was exclusively nuclear in both groups. However, in one of the AIN III sections staining was intense and diffuse, similar to the distribution of staining in the areas of AIN III adjacent to invasive tumours. There was no record of invasive anal disease in

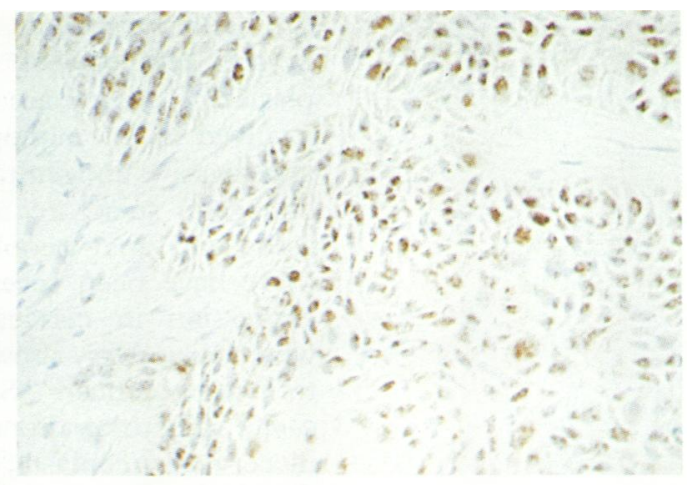

(B)

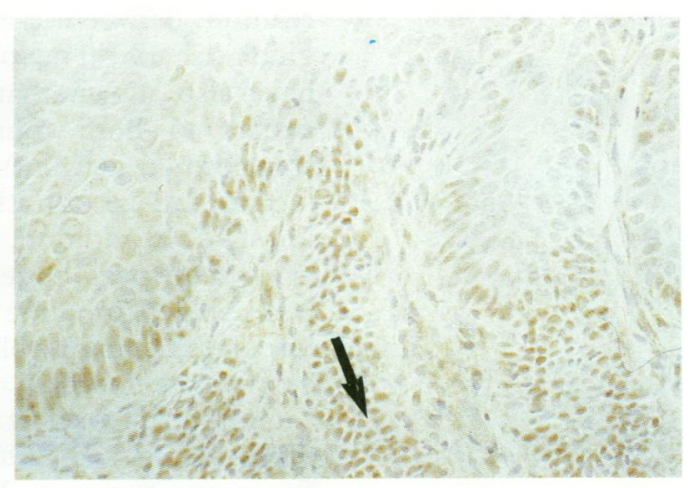

(D)

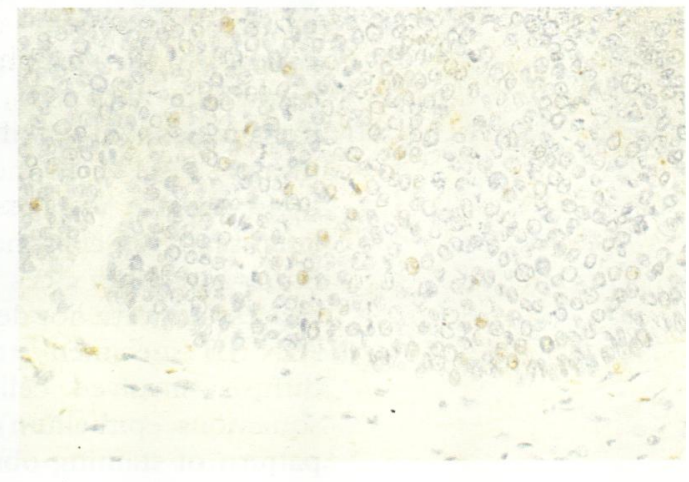

(F)

the patient from whom this specimen was obtained, and clinical follow up to date has not revealed any evidence of further disease. Staining was not observed in any of the negative control specimens.

\section{Discussion}

Several published studies have shown c-myc overexpression in neoplastic lesions, ${ }^{1} 1213171821-24$ although its precise role in the neoplastic process is unknown. There is evidence of progression of c-myc overexpression from normal tissues through preinvasive lesions to invasive tumours in some tissues. ${ }^{182223}$ Several mechanisms have been identified in the deregulation of c-myc expression in tumours and tumour cell lines. These include gene amplification, translocation, mutation and increased production of $c-m y c$ RNA by proviral insertion. ${ }^{27}$

Although there is now compelling evidence 
for a role for human papillomaviruses (HPV) in the aetiology of cervical and anal neoplasia, ${ }^{2829}$ there are probably other factors involved in the pathogenesis of intraepithelial and invasive anogenital neoplasia. ${ }^{30}$ Studies of oncogene structure and expression in HPV associated anal neoplasia are few. However, there have been several studies of oncogene expression in cervical squamous neoplasia, which, like AIN, shows progression of lesions to invasive cancer. ${ }^{31}$ Some studies have shown c-myc structural alteration and overexpression in cervical neoplasia, 51820 and this has been positively correlated with disease progression. However, other studies have failed to show any relation between $c-m y c$ expression and the grade of cervical neoplasia. ${ }^{32}{ }^{33}$ In vitro studies have also shown that amplification of c-myc occurs in both murine and human HPV transformed cell lines, affecting the morphological and growth characteristics of the cell lines. ${ }^{34}{ }^{35}$ In addition, integration of papillomavirus sequences close to the c-myc locus has been shown in some cervical carcinoma cell lines, suggesting a role for HPV and c-myc in cervical carcinoma. $^{3637}$

Our results show that p62 is strongly expressed in well differentiated invasive anal squamous tumours. Importantly, in areas of AIN III and non-dysplastic squamous epithelium adjacent to invasive tumour, the staining characteristics were similar to those of the invasive component-a field effect. This is in contrast to the staining pattern in normal anal epithelium and AIN III specimens obtained from patients in whom there is no evidence of invasive disease. In these groups expression of c-myc protein was less intense, involving isolated scattered cells mainly in the basal epithelium, and differences in the pattern of c-myc expression were not detected. However, in one AIN III specimen staining was intense and diffuse (involved cells in all layers of the squamous epithelium). This is similar to the pattern of staining observed in those areas of AIN III adjacent to invasive tumours. At follow up (one year), recurrent AIN III or invasive tumour had not been detected in the patient studied. She has, however, been treated for high grade cervical and vulval intraepithelial neoplasia and invasive vulval cancer. In view of the parallels drawn between genital and anal neoplasia and the results of this study, it would appear that this patient may have a higher risk of recurrent AIN III and of developing invasive

Table 2 Comparison between c-myc amplification and p62 staining in invasive anal squamous carcinoma

\begin{tabular}{lllc}
\hline Case No & Histology & $C$-myc amplification & $\begin{array}{c}C-\text {-myc } \\
\text { p62 staining }\end{array}$ \\
\hline 812 & Well differentiated & $10 \mathrm{n}$ & +++ \\
839 & Well differentiated & $6 \mathrm{n}$ & +++ \\
682 & Well differentiated & $6 \mathrm{n}$ & +++ \\
881 & Well differentiated & $8 \mathrm{n}$ & +++ \\
659 & Well differentiated & $6 \mathrm{n}$ & +++ \\
303 & Well differentiated & $6 \mathrm{n}$ & +++ \\
804 & Well differentiated & $2 \mathrm{n}$ & +++ \\
707 & Well differentiated & $2 \mathrm{n}$ & +++ \\
767 & Well differentiated & $4 \mathrm{n}$ & +++ \\
750 & Well differentiated & $8 \mathrm{n}$ & 0 \\
868 & Poorly differentiated & $2 \mathrm{n}$ & 0 \\
789 & Poorly differentiated & $2 \mathrm{n}$ & \\
\hline
\end{tabular}

anal cancer. These results suggest that c-myc oncogene overexpression may be implicated in the pathogenesis of anal neoplasia and that AIN III may be premalignant. The apparent decline of $c-m y c$ expression with poorly differentiated tumours is similar to that seen in colorectal and testicular tumours ${ }^{243}$ and would also be consistent with a role for the gene product in cellular differentiation.

The results of this study are similar to those obtained in two previous studies investigating the status of $c-m y c$ in invasive anal squamous neoplasia: they implicate deregulation of the c-myc oncogene in the pathogenesis of anal neoplasia. The first study ${ }^{39}$ showed amplification of the c-myc locus in only $30 \%$ of 50 anal cancers and in no cases of AIN III or those with normal anal epithelium. This suggested that deregulation of c-myc occurred late in the neoplastic process. The second study also showed pronounced c-myc amplification in 25 of $31(80 \%)$ anal squamous tumours compared with no amplification in normal anal epithelium. ${ }^{40}$ Our study is the first to suggest that deregulation of the c-myc gene may occur earlier in the pathogenesis of anal squamous neoplasia. Larger studies are required to confirm these results. Twelve of the tumours examined in our study have been analysed for c-myc amplification by DNA hybridisation. ${ }^{40}$ Eight of these tumours were well differentiated histologically and stained positively for p62 $c-m y c$ in the present study, had marked amplification of the c-myc locus, (table 2) showing a good correlation $(66.6 \%)$ between c-myc amplification and expression. However, two tumours which stained positively for p62 did not demonstrate amplification, suggesting that mechanisms other than gene amplification may result in c-myc deregulation. Increased $\mathrm{mRNA}$ and protein stability and proviral insertion (acting as trans or cis activators) may be responsible. Two poorly differentiated tumours which were negative for p62 did not demonstrate amplification at the c-myc locus.

In conclusion, although this is a relatively small study, these results strongly suggest that c- $m y c$ oncogene expression is implicated in the pathogenesis of anal squamous neoplasia, and that immunohistochemical detection of $c-m y c$ protein (p62) may be useful in identifying those AIN III lesions likely to progress to invasive tumours.

We thank Mrs P Garston for technical advice on immunohistochemical staining techniques, and $\mathrm{Mr} \mathrm{J}$ M A Northover and $\mathrm{Mr}$ $\mathrm{K}$ Miller for providing the specimens from St Mark's Hospital, London.

1 Cooper GM, Lane MA. Cellular transforming genes and oncogenesis. Biochim Biophys Acta 1984;738:9.

2 Bishop JM. Viral oncogenes. Cell 1984;32:23-36.

3 Muller R, Slamon DJ, Tremblay J, Cline M, Verma IM. Differential expression of cellular oncogenes during pre and post natal development of the mouse. Nature
1982;299:640-4.

4 Pfeifer-Ohlsson S, Goustin AS, Rydnert J, et al. Spatial and temporal pattern of cellular myc oncogene expression in developing human placenta: Implications for embryonic cell proliferation. Cell 1984;38:585-96.

5 Pfeifer-Ohlsson S, Rydnert J, Goustin AS, Larsson E, Betshottz C, Ohlsson R. Cell type specific pattern of myc proto-oncogene expression in developing humar

6 Goyette M, Petropoulis CJ, Shank PR, Fausto N. Regulated transcription of c-ki-ras and c-myc compensatory growth
trate transcription of c-ki-ras and c-myc comp.
of rat liver. Mol Cell Biol 1984;4:1493-8. 
7 Little CD, Nau MM, Carney DN, Gazdar AE, Minna JD. Amplification and expression of the c-myc oncogene in human lung cancer cell lines. Nature 1983;306:194-6.

8 Slamon DJ, Dekernion JB, Verma IM, Cline MJ. Expression of cellular oncogenes in human malignancies. Science 1984;224:256-62.

9 Ocadiz R, Sauceda R, Cruz M, Graef AM, Gariglio P. High correlation between molecular alterations of the c-myc oncogene and carcinoma of the uterine cervix. Cancer Res oncogene and carcin

10 Bishop JM. Retroviruses and cancer genes. Adv Cancer Res 1982;37:1-32.

11 Colby WW, Chen EY, Smith DH, Levinson AD. Identification and nucleotide sequence of a human locus homologue to the v-myc oncogene of avian myelocytomatosis virus MC29. Nature 1983;301:722-5.

12 Johnson BE, Ihde DC, Makuch RW, et al. Myc family oncogene amplification in tumour cell lines established from small cell lung cancer patients and its relationship to clinical status and course. $\mathcal{f}$ Clin Invest 1987;79: 1629-34.

13 Escot C, Theillet C, Lidereau R, et al. Genetic alteration of the c-myc proto-oncogene (myc) in human primary breast carcinomas. Proc Natl Acad Sci USA 1986;83:4834-8.

14 Alitalo K, Schwab M, Lin CC, Varmus HE, Bishop JM. Homogenously staining chromosomal regions contain
amplified copies of an abundantly expressed cellular amplified copies of an abundantly expressed cellular
oncogene (c-myc) in malignant neuroendocrine cells oncogene (c-myc) in malignant neuroendocrine cells from a human colo

15 Rothberg PG, Erisman MD, Diehl RE, Rouigatti HG, Astrin SM. Tumour material from patients with haemopoietic malignancies. Mol Cell Biol 1984;4:1096-103.

16 Yokota J, Tsvnetsugi-Yokota Y, Battifora H, Le-Fevre C, Cline MJ. Alterations of myc, myb, and Ha-ras protooncogenes in cancers are frequent and show clinical correlation. Science 1986;231:261-5.

17 Erisman MD, Rothberg PG, Diehl RE, Morse CC, Spandofer JM, Astrin SM. Deregulation of c-myc gene dofer JM, Astrin SM. Deregulation of c-myc gene by amplification or re-arrangement of the gene. Mol Cell Biol 1985;5:1969-76.

18 Pinion SB, Kennedy JH, Miller RW, Maclean AB. Oncogene expression in cervical intraepithelial neoplasia and invasive cancer of the cervix. Lancet 1991;337:819-20.

19 Di Luca D, Costa S, Monini P, et al. Search for human papillomavirus, herpes simplex virus and c-myc oncogen in human genital tumours. Int $f$ Cancer 1989;43:570-7.

20 Riou G, Barrios M, Le MG, George M, Le Doussal V, Haie C. C-myc proto-oncogene expression and prognosis in early carcinoma of the cervix. Lancet 1987;i:761-3.

21 Polacarz SV, Darne J, Sheridan EG, Ginsberg R, Sharp F. $C$-myc oncogene expression in premalignant and malignant glandular lesions of the uterine cervix and the demonstration of field change effects. $f$ Pathol 1990; 160:167.

22 Stewart J, Evan G, Watson J, Sikora K. Detection of the c-myc oncogene product in colonic polyps and carcinomas. $B r f$ Cancer 1986;53:1-6.

23 Subdaresan V, Forgacs IC, Wight DGD, Wilson B, Evan GI, Watson J. Abnormal distribution of c-myc oncogen product in familial adenomatous polyposis. $\mathcal{F}$ Clin Patho 1987;40:1274-81.
24 Sikora K, Evan G, Stewart J, Watson JV. Detection of the c-myc oncogene product in testicular cancer. $\mathrm{Br} \mathcal{F}$ Cancer 1985;52:171-6.

25 Warnke $R$, Levy $R$. The detection of $T$ and $B$ cell antigens with hybridisation monoclonal antibodies. A biotinavidin-horseradish proxidase method. $\mathcal{f}$ Histochem Cytochem 1980;28:771.

26 Evan GI, Lewis GK, Ramsay G, Bishop JM. Isolation of monoclonal antibodies specific for human c-myc protomonocional antibodies sell Biol 1985;5:3610-36.

27 DePinho RA, Schreiber-Agus N, Alt FW. Myc family oncogene in the development of normal and neoplastic
cells. In: Vande Woude GF, Klein G, eds. Advances in cells. In: Vande Woude GF, Klein G, eds. Advances in cancer

28 Zur Hausen $H$. Papillomaviruses in human cancers. Molecular Carcinogenesis 1989;1:147-50.

29 Palmer JG, Scholefield JH, Coates PJ, et al. Anal squamous cell carcinoma and human papillomaviruses. Dis Colon Rectum 1989;32:1016-22.

30 Zur Hausen H. Papillomaviruses as carcinoma viruses. In Klein G, ed. Advances in viral oncology. New York: Raven Press, 1989:1-26.

31 Scholefield JH, Sonnex C, Talbot IC, et al. Anal and cervica intraepithelial neoplasia: Possible parallel. Lancet 1989; ii:765-8.

32 Hughes RG, Neill WA, Norval M. Papillomavirus and c-myc antigen expression in normal and neoplastic c-myc antigen expression in normal and neopical epithelium. $\mathcal{f}$ Clin Pathol 1989;42:46-51.

33 Hendy-Ibbs P, Cox H, Evan GI, Watson JV. Flow cytometric quantitation of DNA and c-myc oncoprotein in archival biopsies of uterine cervix neoplasia. $\mathrm{Br} f$ Cancer 1987;55:275-82.

34 Crook T, Almond N, Murray A, Stanley M, Crawford L. Constitutive expression of c-myc oncogene confers hormone independence and enhanced growth factor responsiveness on cells transformed by human papillomavirus type 16. Proc Natl Acad Sci USA 1989;86:5713-7.

35 Crook T, Greenfield I, Howard J, Stanley M. Alterations in growth properties of human papillomavirus type 16 growth properties of human papillomavirus type 16 immortalised human cervical keratinocyte cell line corre-
late with amplification and overexpression of c-myc late with amplification and overexpr

36 Couturier J, Sastre-Garau X, Schneider-Maundury $S$ Labib A, Orth G. Integration of papillomavirus DNA near myc genes in genital carcinomas and its consequences for proto-oncogene expression. $\mathcal{F}$ Virol 1991;65:4534-8.

37 Durst M, Croce CM, Gissmann L, Schwarz E, Huebner K Papillomavirus sequences integrate near cellular oncogenes in some cervical carcinomas. Proc Natl Acad $S_{c i}$ USA 1987;84:1070-4.

38 Sikora K, Chan S, Evan G, et al. C-myc oncogene expression in colorectal cancer. Cancer 1987;59. $1289-95$.

39 Crook T, Wrede D, Tidy J, Scholefield J, Crawford L Vousden KH. Status of c-myc, p53 and retinoblastoma genes in human papillomavirus positive and negative squamous cell carcinomas of the anus. Oncogene 1991 6:1251-7.

40 Scholefield JH. Studies in the pathogenesis of human papillomavirus associated anal squamous cell carcinoma. Thesis. University of Liverpool. 1990:265pp. 